\title{
Treatment with a High Dose Combination of PMSG/hCG Preparation of Mares Clinically Diagnosed with Ovarian Quiescence during the Breeding Season (Investigation from 1975 to 2000)
}

\author{
Tsutomu TSUKADA ${ }^{1}$, Kunitada SATO ${ }^{2}$, Masaharu MORIYOSHI ${ }^{3 *}$, Masanori KOYAG ${ }^{3}$ and \\ Yutaka SAWAMUKAI ${ }^{3}$ \\ ${ }^{1}$ Tsukada Livestock Clinic, Mitsuishi, Hokkaido 059-3231, ${ }^{2}$ Department of Veterinary Medicine, Obihiro \\ University of Agriculture and Veterinary Medicine, Obihiro, Hokkaido 080-8555, ${ }^{3}$ Department of Veterinary \\ Medicine, Rakuno Gakuen University, Ebetsu, Hokkaido 069-8501, Japan
}

A total of 88 thoroughbred mares were diagnosed with clinical ovarian quiescence and subjected to four treatment regimens. Using PMSG, hCG or combinations of both. A high dose combination of 5,000IU PMSG with 5,000IU hCG showed significantly higher rates of marked estrus and ovulation induction $(P<0.01)$ as well as conception rates $(P<0.05)$. In the present study, the administration of a high-dose combination of PMSG with hCG was shown to be an effective treatment of ovarian quiescence in light mares.

Key words: fertility, mare, ovarian quiescence, $P M S G / h C G$ preparation
J. Equine Sci.

Vol. 19, No. 2

pp. 35-38, 2008
Alvarenga, et al. [1] and Tsukada, et al. [18, 19] reported successful induction of follicular maturation and ovulation in mares following administration of equine pituitary extract, and PMSG, hCG and porcine FSH. The effect of hCG administration on inducing ovulation in mares was also reported by Gastal, et al. [4] and Wilson, et al. [20]. On the other hand, Miyake and Sato [8] reported that hCG administration did not produce satisfactory results in artificially inducing ovulation or treating ovarian quiescence and ovulation failure. Nishikawa [10] concluded that the ovulation induction rate after PMSG administration in mares was lower than in other animals, thus requiring other more effective treatment methods to be examined $[6,12]$. Furthermore, low dose PMSG treatment did not effect mare follicle development $[3,11,21]$. Therefore, we postulated that administration of a high dose of PMSG and hCG would stimulate and lead to more follicle development for several days. In the present study, we examined the effectiveness of different dosages of

This article was accepted February 29, 2008

*Corresponding author. e-mail : moriyosi@rakuno.ac.jp
PMSG and hCG and their combination in the treatment of equine ovarian quiescence. Low dose PMSG or hCG and combinations of high or low dose PMSG and hCG were administered once to mares with ovarian quiescence and the therapeutic performance was compared among the treatment groups.

The present study included 88 thoroughbred mares, which were fed and managed according to normal routines at commercial stud farms in the Hidaka district of Hokkaido. The administration data were obtained during the breeding season between the beginning of May and the beginning of July 1975 to 2000. The age range of the animals was 5 to 20 years, and their weight range was 450 to $550 \mathrm{~kg}$. Eighty-four mares had prior pregnancy histories but were anestrous following delivery or mating, or anestrous without pregnancy during the previous year. The remaining four animals had no prior pregnancy history and were anestrous after mating. None of these animals responded to teasing and intramuscular $\mathrm{PGF}_{2 \alpha}$ administration before the experimental hormone treatments. Thereafter, all were diagnosed with ovarian quiescence, because rectal palpations at 7 to 10 
Table 1. Reproductive performance following administration of gonadotropic hormone products as treatment for ovarian quiescence in mares

\begin{tabular}{lccccc}
\hline Treatment Group & $\begin{array}{c}\text { No. of mares } \\
\text { tested }\end{array}$ & $\begin{array}{c}\text { No. of mares } \\
\text { exhibiting estrus }(\%)^{1)}\end{array}$ & $\begin{array}{c}\text { No. of mares } \\
\text { subjected to mating }\end{array}$ & $\begin{array}{c}\text { No. of mares } \\
\text { ovulating }(\%)^{2)}\end{array}$ & $\begin{array}{c}\text { No. of } \\
\text { conception }(\%)^{3)}\end{array}$ \\
\hline PMSG/hCG(high) & 35 & $26(74.3)$ & 22 & $26(100)^{\mathrm{A}}$ & $18(81.8)^{\mathrm{a}}$ \\
PMSG/hCG(low) & 18 & $13(72.2)$ & 9 & $9(69.2)^{\mathrm{B}}$ & $7(77.8)$ \\
PMSG & 2 & $1(50.0)$ & 1 & $1(100)$ & $1(100)$ \\
hCG & 33 & $22(66.7)$ & 13 & $13(59.0)^{\mathrm{B}}$ & $5(38.4)^{\mathrm{b}}$ \\
\hline
\end{tabular}

PMSG/hCG(high), a combination of 5,000IU PMSG with 5,000IU hCG, PMSG/hCG(low), 2,000IU PMSG and 2,500IU hCG combination, PMSG, 2,000IU PMSG or hCG, 2,500IU hCG were administered to each mare intramuscularly.

1) Number of mares that exhibited estrus within 3 weeks after receiving test drug.

2) Number of mares in which ovulation was confirmed, among estrus-induced mares.

${ }^{3)}$ Number of mares that conceived as a result of mating during the induced estrous period. Four mares each in PMSG/hCG(high) and PMSG/hCG(low) treatment groups and nine mares in hCG treatment group were excluded from mating due to the dicision of their owners.

$\mathrm{A} / \mathrm{B}(\mathrm{P}<0.01), \mathrm{a} / \mathrm{b}(\mathrm{P}<0.05)$.

day intervals either failed to detect follicular growth in the ovaries, or revealed small follicles that persisted for a prolonged period without growth. Estrous behavior in the animals was detected by teasing every second day and rectal palpation at 4 to 5 day intervals after treatment.

On the day of diagnosis, the mares were randomly divided into four treatment groups as follows: 35 mares received a combination of 5,000 IU PMSG with 5,000 IU hCG (high PMSG/hCG group), 18 received a combination of a PMSG 2,000 IU aqueous preparation with an hCG 2,500 IU oil preparation (low PMSG/hCG group), 2 received a PMSG 2,000 IU aqueous preparation (PMSG group) and 33 received an hCG 2,500 IU oil preparation (hCG group). Therapeutic effects were compared by the number of mares exhibiting estrus (\%) within 3 weeks of treatment, and by the number of mares ovulating (\%) and conceiving (\%) during the same estrous period. In the statistical analysis, the $\chi^{2}$ test was used to determine the differences in the therapeutic performance among the treatment groups. Differences were considered to be significant at $\mathrm{P}<0.01$ or 0.05 unless stated.

In the high PMSG/hCG group, 26 mares $(74.3 \%)$ experienced estrous induction within three weeks of treatment, and in all of these mares, ovulation was confirmed by rectal palpation before the end of their estrous period (Table 1 ). Eighteen $(81.8 \%$ ) out of 22 mares conceived as a result of mating during the induced estrous period. In the low PMSG/hCG group, 13 mares $(72.2 \%)$ exhibited estrus and $9(69.2 \%)$ of these animals ovulated. Seven $(77.8 \%)$ out of 9 mares conceived as a result of mating during the induced estrous period. In the hCG group, 22 mares (66.7\%) exhibited estrus and $13(59.0 \%)$ of 22 mares experienced ovulation. However, only 5 (38.4\%) of 13 mares conceived as a result of mating. From these results, high and low dose PMSG/hCG treatments were more effective at inducing estrus than the hCG treatment. High dose PMSG/hCG treatment was significantly effective at inducing ovulation compared to low dose PMSG/hCG and hCG treatments $(\mathrm{P}<0.01)$. The conception rate in the high PMSG/hCG group was $81.8 \%$, which was also clearly higher than the $38.4 \%$ observed in the hCG group $(\mathrm{P}<0.05)$.

The medical treatment rates of ovarian quiescence in reproductive organ diseases during the breeding season in light breed horses have remained static in the range of 3-5\% in Hokkaido [14-17]. Trials and studies on hormonal methods have been conducted with LH and $\mathrm{FSH}$, and various combinations of other hormones for induction of ovulation or follicle development in mares [6], but their effectiveness and dosage frequency requirements have not been confirmed by other researchers [12]. In other research experiments, nonequine pituitary preparations have been unsuccessful at inducing follicular development. Practitioners have occasionally performed further studies. Ginther [6] and Nambo et al. [9] postulated that in the mare only one follicle is normally selected to proceed to ovulation because of a FSH inhibitor substance secreted by other follicles. The administration of 1,000 IU PMSG into equine small follicles significantly developed the follicles to a greater degree than the control [5]. High dose PMSG initiates development of mare follicles since PMSG significantly binds LH receptors of theca 
interna cells compared to other hormones and substances in spite of not having a strong affinity to LH receptors [13]. Furthermore, PMSG continues LH-like action for several days following its administration and brings about the ovulation of the developed follicle. The administration of hCG significantly increased MMP-2 which is related to the development of mare follicles in vitro [2]. Therefore, hCG may stimulate follicle development. Kojima [7] showed that hCG increases $\mathrm{PGF}_{2 \alpha}$ secretion of mare follicles. Ginther [6] reported that $\mathrm{PGF}_{2 \alpha}$ treatment could cause a delayed, prolonged LH release in mares. Their results add support to the theory that $\mathrm{PGF}_{2 \alpha}$ might stimulate ovulation of developed follicle mares. Therefore, we speculate that follicular maturation induced by the high dose combination of PMSG/hCG treatment may have been due to $\mathrm{PGF}_{2 \alpha}$ secretion. The present results reveal the effectiveness of the high dose combination of $\mathrm{PMSG} / \mathrm{hCG}$ for the treatment of ovarian quiescence in light horses. If PMSG and hCG have a significant impact on the growth of small and medium follicles and the induction of ovulation, respectively, the high dose combination of PMSG/hCG should be effective for the treatment of ovarian quiescence.

\section{References}

1. Alvarenga, M.A., Bruemmer, M.P., Neves, J., Neto, J.R., and Squire, E.L. 2001. Ovarian superstimulatory response and embryo production in mares treated with equine pituitary extract twice daily. Theriogenology 56: 879-887.

2. Devousges, A.L., and Sharp, D.C. 2005. Ovarian tissue remodeling and pre-ovulatory follicle development. Havemeyer Foundation Monograph Series 14: 25-27.

3. Douglas, R.H. 1979. Review of induction of superovulation and embryo transfer in the equine. Theriogenology 11: 33-46.

4. Gastal, E.L. 2006. Effective of different dose of hCG on diameter of the preovulatory follicle and interval to ovulation in mares. Anim. Reprod. Sci. 94: 186-190.

5. Gastal, E.L., Kok, K., and Ginther, O.J. 1995. Ultrasound-guided intrafollicular treatment in mares. Theriogenology 44: 1027-1037.

6. Ginther, O.J. 1982. Endocrinology of the ovulatory season. pp. 233-290. In: Reproductive Biology of the Mare, 2nd ed., Equiservices, Wisconsin.

7. Kojima, A.Y. 2001. Study on the localized regulation system of vasoactive substances associated with equine ovarian function. Gifu University, United Graduate School of Veterinary Science, Gifu.

8. Miyake, M., and Sato, K. 1992. Manual for increasing farm horse production. pp. 46-47. Hokkaido Veterinary Medical Association, Sapporo (in Japanese).

9. Nambo, Y., Kaneko, H., Nagata, S., Oikawa, M., Yoshihara, T., Nagamine, N., Watanabe, G., and Taya, K. 1998. Effect of passive immunization against inhibin on FSH secretion, folliculogenesis and ovulation rate during the follicular phase of the estrous cycle in mares. Theriogenology 50: 545557.

10. Nishikawa, Y. 1959. Effect of Gonadotropic hormone to mare ovaries, especially comparison to other animals. pp.126-137. In: Studies on Reproduction in Horses Singularity and Artificial Control in Reproductive Phenomena, Japan Racing Association, Tokyo (in Japanese).

11. Palmer, E., Hajmeli, G., and Duchamp, G. 1993. Gonadotrophin treatments increase ovulation rate but not embryo production from mares. Equine Vet. J. (Suppl) 15: 99-102.

12. Rossdale, P.D., and Ricketts, S.W. 1980. The oestrous cycle. pp. 11-42. In: Equine Stud Farm Medicine, Bailliere Tindall, London.

13. Sasamoto, S., and Taya, K. 1988. Hormone hand book. pp. 275-298. In: The Japan Society for Comparative Endocrinology, Nanzando, Tokyo (in Japanese).

14. The number of patient domestic animals in Hokkaido. 2002. In: An Annual Report of Domestic Animal Medical Care in 2003. pp. 58-59. Hokkaido government, Sapporo (in Japanese).

15. The number of patient domestic animals in Hokkaido. 2003. In: An Annual Report of Domestic Animal Medical Care in 2004. pp.59-60. Hokkaido government, Sapporo (in Japanese).

16. The number of patient domestic animals in Hokkaido. 2004. In: An Annual Report of Domestic Animal Medical Care in 2005. pp. 57-58. Hokkaido government, Sapporo (in Japanese).

17. The number of patient domestic animals in Hokkaido. 2005. In: An Annual Report of Domestic Animal Medical Care in 2006. pp. 58-59. Hokkaido government, Sapporo (in Japanese).

18. Tsukada, T., Ikemoto, Y., Kawaguchi, M., and Imamichi, T. 1975. Effects of the FSH treatment on ovarian follicular cyst and ovulation failure in light breed mares. Jpn. J. Animal Reprod. 21: 7-11 
(in Japanese with English abstract).

19. Tsukada, T., Ikemoto, Y., and Kawaguchi, M. 1975. Effects of highest doses of PMS and hCG combined or not combined with intrauterine infusion on the hypovaria in light breed mares. Jpn. J. Animal Reprod. 21: 12-17 (in Japanese with English abstract).

20. Wilson, C.G., Downie, C.R., Hughes, J.P., and
Roser, J.F. 1990. Effects of repeated hCG injections on reproductive efficiency in mares. Equine Vet. Sci. 10: 301-308.

21. Woods, G.L., Scraba, S.T., and Ginther, O.J. 1982. Prospects for induction of multiple ovulations and collection of multiple embryos in the mare. Theriogenology 17: 61-72. 